\title{
Recent Advances and Insights into Bromelain Processing, Pharmacokinetics and Therapeutic Uses
}

\author{
Alessandro Colletti ${ }^{1}$, Shuyi Li $^{1,2}{ }^{1,}$ Mauro Marengo ${ }^{1} \mathbb{D}$, Salvatore Adinolfi ${ }^{1}$ and Giancarlo Cravotto $^{1,3, *(\mathbb{D})}$ \\ 1 Department of Drug Science and Technology, University of Turin, Via P. Giuria 9, 10125 Turin, Italy; \\ alessandro.colletti@unito.it (A.C.); lishuyisz@sina.com (S.L.); mauro.marengo@unito.it (M.M.); \\ salvatore.adinolfi@unito.it (S.A.) \\ 2 National R\&D Center for Se-Rich Agricultural Products Processing Technology, College of Food Science and \\ Engineering, Wuhan Polytechnic University, Wuhan 430023, China \\ 3 World-Class Research Center "Digital Biodesign and Personalized Healthcare", Sechenov First Moscow State \\ Medical University, 8 Trubetskaya ul, 119991 Moscow, Russia \\ * Correspondence: giancarlo.cravotto@unito.it; Tel.: +39-011-670-7183
}

Citation: Colletti, A.; Li, S.; Marengo, M.; Adinolfi, S.; Cravotto, G. Recent Advances and Insights into Bromelain Processing, Pharmacokinetics and Therapeutic Uses. Appl. Sci. 2021, 11, 8428. https://doi.org/10.3390/ app11188428

Academic Editor: David Charles Barton

Received: 12 August 2021

Accepted: 7 September 2021

Published: 10 September 2021

Publisher's Note: MDPI stays neutral with regard to jurisdictional claims in published maps and institutional affiliations.

Copyright: (C) 2021 by the authors Licensee MDPI, Basel, Switzerland. This article is an open access article distributed under the terms and conditions of the Creative Commons Attribution (CC BY) license (https:// creativecommons.org/licenses/by/ $4.0 /)$

\begin{abstract}
Bromelain is a mixture of proteolytic enzymes that is extracted primarily from pineapples. It is present in almost all the aerial parts of the plant—-the peels, leaves, stems and fruit-although only the fruit and stems contain significant amounts. The market-demand for bromelain is quickly increasing, especially in the health sector as it can be used as a drug and/or nutraceutical. Although the complete molecular mechanism has not been fully identified, bromelain possesses several properties, including anti-inflammatory, anti-oedema, antithrombotic and fibrinolytic, mucolytic, anticancer and cicatrizing effects that have been evaluated in several clinical trials. However, one of the main limitations for the clinical use of this supplement is the varying composition of extracts, which leads to heterogeneity in results and, therefore, difficulty in making evidence-based prescriptions. In fact, different geographic locations, land and modes of cultivation, as well as extraction methods, can all give extracts with different activities, depending on the plant part used. Additionally, although novel extraction techniques have been developed to improve bromelain purification and extraction and give higher yields without loss in enzymatic activity, these methods are still expensive and challenging. This review will describe the state of the art in the main conventional and unconventional extraction and purification methods of bromelain and discuss the advantages and limitations of these strategies. Pharmacokinetic and pharmacodynamic profiles and the clinical applications that have arisen from randomized controlled clinical trials are also discussed. Finally, future perspectives for bromelain extracts will be presented.
\end{abstract}

Keywords: bromelain; pineapple; inflammation; extraction methods; clinical trials

\section{Introduction}

Bromelain is a mixture of proteolytic enzymes that is extracted primarily from pineapples (Ananas comosus) that is well known and used in several fields, especially in the nutraceutical and cosmeceutical sectors [1]. It was first identified by Marcano in 1891 in pineapple juice, and Heinecke discovered higher amounts of bromelain in the stem than the fruit in 1957 [2]. Although bromelain was initially defined as the mixture of enzymes produced in the fruit, today, this term includes any protease extracted from any member of the Bromeliaceae family [3]. Pineapple is the most common plant from which bromelain is extracted. The proteases that constitute bromelain are cysteine endopeptidases, which catalyze the hydrolysis of the peptide bonds of non-terminal amino acids [4]. Bromelain usually includes glycosidases, phosphatases, ribonuclease, cellulases, peroxidases and glycoproteases, which primarily cleave alanyl, glycyl and leucyl peptide bonds. These enzymes are present in different ratios that depend on a number of factors, including the geographic location of the plant, the land and mode of cultivation, the extraction method, 
and the part of the plant used [5]. In fact, although bromelain is present in almost all of the aerial parts of the plant-the peels, leaves, stems and fruit-only the fruit and stems are rich in bromelain. In particular, the bromelain in pineapple stems (EC number 3.4.22.32) is the most abundant protease, with an isoelectric point (pI) of 9.5 and optimum $\mathrm{pH}$ range of 6-7, while the bromelain found in pineapple fruit (EC number 3.4.22.33) is present in lower amounts, with a $\mathrm{pI}$ of 4.6 and an optimum $\mathrm{pH}$ range of 3-8 [6,7]. These significant differences in bromelain composition, probably due to the presence of different thiol-endopeptidases, may, in part, explain the great heterogeneity of clinical and preclinical results for potential effects on a wide category of conditions, including inflammatory diseases, cancer, immune dysfunction and others [8].

The demand for bromelain is increasing quickly, and the reason for this great interest in the clinical field is related to its anti-inflammatory, antiedematous, fibrinolytic, anticancer, anticoagulative and antithrombotic properties that have been thoroughly described in the literature [3]. In addition, this enzymatic complex is used in other sectors, including cosmetics, breweries, flesh processing and tenderisation, and textile industries $[7,9,10]$. However, the isolation and purification of bromelain from pineapple (fruit, stem, core, leaves) is a challenge and constitutes $70-90 \%$ of the total production cost of the final extract [11]. To date, the commercial cost of bromelain extracts is high, with prices hovering around $2400 \mathrm{USD} / \mathrm{kg}$ [12]. The development of methods to achieve highly purified bromelain in fewer steps is therefore necessary to decrease overall production costs [3]. Despite the new feasible methods of protein purification (e.g., membrane filtration, reverse micellar systems, aqueous two-phase extraction, chromatographic techniques) and the new biotechnological processes developed to mitigate production costs, several limitations still create problems for the efficiency of product recovery from crude-plant extracts and the effectiveness of the obtained extract [12]. In fact, the enzyme complex tends to be irreversibly inactivated at high temperatures (e.g., during the pasteurization process), while the progressive concentration of bromelain in crude pineapple juice during the purification process can induce spontaneous enzymatic deactivation [5].

This review will describe the state of the art in the main conventional and unconventional extraction and purification methods of bromelain and discuss the advantages and limitations of these strategies. Pharmacokinetic and pharmacodynamic profiles and the clinical applications that have arisen from randomized controlled clinical trials (RCTs) are also discussed. Finally, future perspectives for bromelain extracts will be presented.

\section{Physicochemical Properties of Bromelain}

Pineapple-stem bromelain belongs to the class of $\alpha+\beta$ proteins that are characterized by a single polypeptide chain, either 211 or 212 amino acids in length, and have an estimated molar mass of $22.8 \mathrm{kDa}$. The amino acid sequences of bromelain are homologous to those of papain, chymopapain and actinidin [13]. A single oligosaccharide chain has been reported to be conjugated to this polypeptide, making the molar mass of stem bromelain around $23.8 \mathrm{kDa}[14]$.

Many studies have shown that the proteolytic activity of bromelain is only partly connected to its pharmacological effects, suggesting that evaluating the whole phytocomplex, including the non-protein factors [7], is of great importance. The most prominent cysteine endopeptidases in pineapple tissues, other than stem and fruit bromelain, are ananain and comosain, whose physicochemical characteristics are summarized in Table $1[15,16]$.

Bromelain remains intact for a relatively long time when stored at $-20{ }^{\circ} \mathrm{C}$, while its proteolytic activity is lost, via bromelain degradation, when it is heated to $100{ }^{\circ} \mathrm{C}$ for $10 \mathrm{~min}[15,17]$. Khan and colleagues have demonstrated that the maximum activity of glycosylated bromelain occurs at $\mathrm{pH} 7.0$ and $30^{\circ} \mathrm{C}$ [18]. The activity of the protease complex decreases by $17 \%$ at $40-60{ }^{\circ} \mathrm{C}$ and, upon lowering the $\mathrm{pH}$ to $3.0-4.0$, the optimum temperature was found to decrease with a higher sensibility for the deglycosylated rather than the glycosylated form [18]. 
Bhattacharya et al. have investigated the activity of bromelain after storage at $30{ }^{\circ} \mathrm{C}$ for 30 days, and $4{ }^{\circ} \mathrm{C}$ for 60 days. Their results show a retention of activity after storage of $22 \pm 2 \%$ and $44 \pm 2 \%$ under these respective conditions, highlighting that there is an inverse correlation between storage temperature and the retention of enzymatic activity [19]. As for $\mathrm{pH}$, bromelain activity was shown to increase up to $\mathrm{pH} 7.0$, showing a decreasing trend thereafter [20].

Table 1. Physicochemical characteristics of pineapple endopeptidases and amino acid composition of both green and ripe fruits (adapted from Rowan and Buttle [15] and Murachi [21]).

\begin{tabular}{|c|c|c|c|c|c|c|c|}
\hline \multirow{2}{*}{ Endopeptidase } & \multicolumn{3}{|c|}{ Amino Acid Composition \% } & \multirow{2}{*}{$\begin{array}{c}\text { Molar Mass } \\
\text { (kDa) }\end{array}$} & \multirow{2}{*}{$\mathrm{pI}$} & \multirow{2}{*}{$A^{1 \%} 280 \mathrm{~nm}$} & \multirow{2}{*}{$\begin{array}{l}\text { Presence of } \\
\text { Glycoproteins }\end{array}$} \\
\hline & & Green Fruit & Ripe Fruit & & & & \\
\hline \multirow{18}{*}{ Fruit bromelain } & Lysine & 7.8 & 8.3 & \multirow{18}{*}{$25-31$} & \multirow{18}{*}{4.6} & \multirow{18}{*}{19.2} & \multirow{18}{*}{ Yes } \\
\hline & Histidine & 1.4 & 1.3 & & & & \\
\hline & Arginine & 8.6 & 9.1 & & & & \\
\hline & Aspartic Acid & 29.8 & 29.8 & & & & \\
\hline & Threonine & 13.8 & 13.8 & & & & \\
\hline & Serine & 32.2 & 32 & & & & \\
\hline & Glutamic Acid & 23.2 & 23.4 & & & & \\
\hline & Proline & 11.6 & 12 & & & & \\
\hline & Glycine & 32.6 & 32.2 & & & & \\
\hline & Alanine & 23.8 & 24.4 & & & & \\
\hline & Cysteine & 10.0 & 10.0 & & & & \\
\hline & Valine & 19.8 & 20.1 & & & & \\
\hline & Methionine & 6.0 & 5.8 & & & & \\
\hline & Isoleucine & 16.4 & 16.2 & & & & \\
\hline & Leucine & 10.0 & 10.0 & & & & \\
\hline & Tyrosine & 22.4 & 22.2 & & & & \\
\hline & Phenylalanine & 7.6 & 8.0 & & & & \\
\hline & Tryptophan & 5.6 & - & & & & \\
\hline Stem bromelain & & - & & $23.8-27$ & 9.5 & 20.1 & Yes \\
\hline Ananain & & - & & $23.4-25$ & $>10$ & 16.5 & No \\
\hline Comosain & & - & & 24.5 & $>10$ & - & Yes \\
\hline
\end{tabular}

\section{Extraction and Purification Methods}

The National Library of Medicine (MEDILINE; January 1970 to June 2021) and the Cochrane Register of Controlled Trials were used in the preparation of this review. The terms used for the electronic search strategy were: 'bromelain', 'pineapple', 'bromelain extract', 'bromelain purification', 'bromelain extraction', 'human' and 'clinical trial'. The selected references were screened, including those regarding clinical applications from clinical trials, and bromelain extraction and purification methods. The work includes a general introduction, an explanation of the main bromelain extraction and purification methods, a brief description of the mechanisms of action, the pharmacokinetics and safety of this enzyme complex and bromelain properties, followed by an exploration of the effects observed in clinical studies divided by therapeutic area.

In general, plant proteases are produced in the early stages of fruit development, as has been demonstrated for papayas [22]. However, bromelain is extracted from pineapple 
when the fruit is mature, with the highest concentration of proteases only being reached at that point [23].

As highlighted in the introduction, the production of bromelain is expensive (price for extract: $2400 \mathrm{USD} / \mathrm{Kg}$ ) [12], as it entails several manufacturing processes, including extraction, purification, drying and packing. Purification is the most significant of all these processes, with it accounting for at least two-thirds of the total cost of bromelain production [5]. Furthermore, no guidelines for bromelain purification are currently available.

The starting product, which can include the fruit, stem and other parts of the pineapple, is usually ground, without adding water, to obtain a raw crude extract. Subsequently, the extract (cooled pineapple juice) is processed further using conventional methods, such as centrifugation, ultrafiltration and lyophilisation, giving a yellowish powder (Figure 1) [24]. However, several unconventional methods have been developed in recent years to improve both enzymatic yield and purity (Table 2) [25].

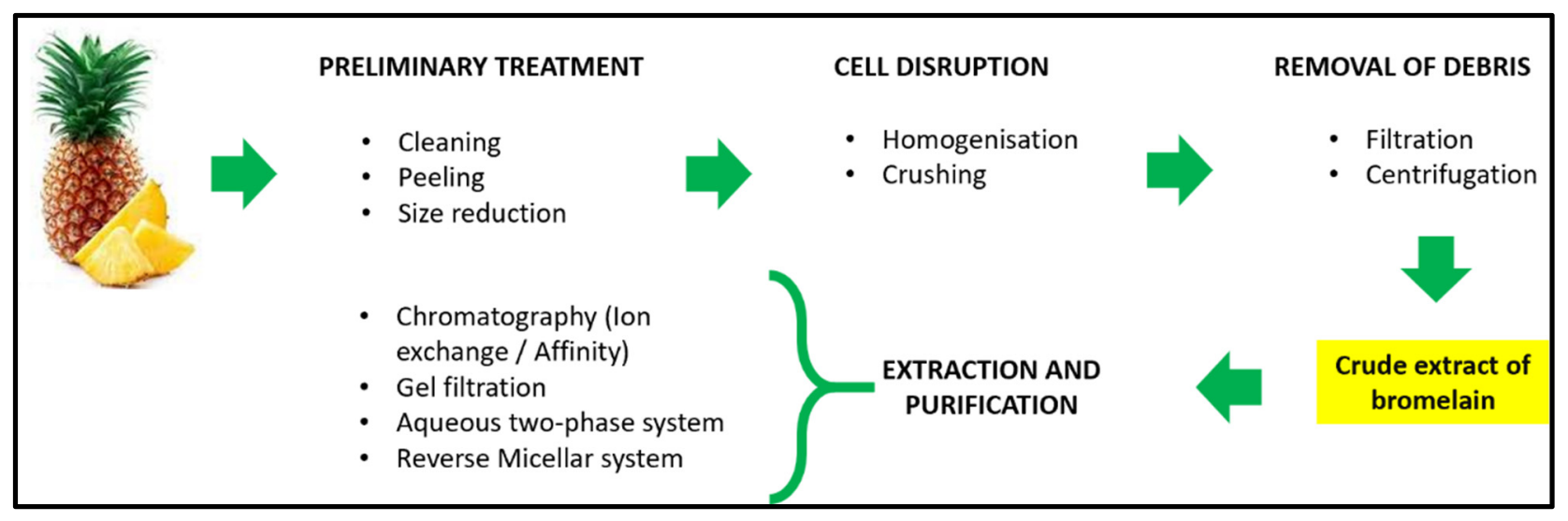

Figure 1. Overview of bromelain extraction and purification methods. Conventional approach: centrifugation, ultrafiltration and lyophilisation.

The conventional approach to bromelain extraction is currently the most widely used. It consists of a first phase in which the raw extract is homogenized to disrupt pineapple cells and it is then centrifuged to remove the particulate material without denaturing the proteases [26]. The enzymatic concentration of stem bromelain has been reported to be higher than that of fruit bromelain [24]. Although centrifugation produces a homogenous extract, subsequent processing is required to eliminate or decrease the quantities of impurities [27]. Ultrafiltration ( 100 $\mathrm{min}$ ) is followed by centrifugation, which is the gold standard for protein concentration, using membranes with molecular weight cut-offs from 3 to $100 \mathrm{kDa}$, leading to an $\sim 8.9$-fold increase in bromelain concentration. Convection (driven by difference in pressure applied to the membrane) and diffusion (driven by concentration gradient across the membrane) are the two main mechanisms that influence mass transfer during membrane filtration [28]. Other effects that can influence mass transfer include dielectric exclusion, steric effects and the Donnan equilibrium [29].

Membrane filtration, used in combination with other processes, has been proven to improve bromelain purification. A study by Doko et al. has reported a yield of $98 \%$ for combined microfiltration, ultrafiltration, ammonium sulphate precipitation and ultracentrifugation, although proteolytic activity was found to be lower by the end of the processes [30]. Chao et al. have obtained $64.7 \%$ activity recovery and a 5.3-fold concentration using nano- $\mathrm{TiO}_{2}$ and ultrafilters [31]. The simultaneous use of both microfiltration (plain membrane) and ultrafiltration (10 $\mathrm{kDa}$ Millipore kit) resulted in activity recovery of $90 \%$ and bromelain that was concentrated 10-fold [32]. Hebbar et al. have used the combined processes of a reverse micellar system and ultrafiltration to purify bromelain from pineapple stems. They demonstrated that bromelain is retained using membranes of $5 \mathrm{kDa}$ with an activity recovery of $95.8 \%$ and a 5.9 -fold concentration [33]. 
The last purification step entails lyophilisation, also known as freeze drying, which removes water from the ultrafiltered bromelain [34]. During the transition of water from a solid to a gas, some proteins and in particular enzymes may be denatured as they shift from a "molecular state" (proteins soluble in water) to a "particle state" (proteins without water). A decrease in bromelain enzymatic activity of more than $50 \%$ has been observed when a lyophilisation step was carried out at the end of a purification protocol [9]. For this reason, stabilizers, such as cryoprotectants, are required to maintain protein stability during the lyophilisation process.

Bresolin and colleagues have used ammonium sulphate precipitation in combination with the desalting and freeze-drying of pineapple peel and obtained an activity recovery of $75 \%$ (after lyophilisation, alone, the specific activity of bromelain decreased to $5.2 \%$ of its original value) [8]. Similar results have been obtained by Devatake et al. with a bromelain fruit extract [35].

\subsection{Unconventional Approaches}

Although conventional methods are frequently and widely used both in laboratories and on an industrial scale, they often present limitations, principally in terms of yield, purification and processing costs. Modern techniques permit the above-mentioned conventional approaches to be used in association with unconventional processes, including gel filtration, aqueous two-phase extraction, extraction via reversed micelles, ion exchange and affinity chromatography. The use of both types of approaches allows an initial prepurification step, which concentrates the enzymatic proteases to be performed with a subsequent step to remove the remaining impurities [5]. The most appropriate technique for the isolation of bromelain also depends on the intended application of the purified enzyme. Nevertheless, a combination of low-resolution (filtration and liquid-liquid extraction) and high-resolution techniques (chromatography) is probably the best approach to limit costs, provide high yields and low-impurity extracts and to retain enzymatic activity.

\section{(A). Aqueous two-phase systems}

Aqueous two-phase systems are a low-cost, environmentally friendly, rapid and scalable technique for the extraction and purification of many compounds, and involves a reusable polymer and a salt, or two reusable polymers [36]. In general, this approach separates proteins and prevents denaturation while removing undesirable contaminants, such as pigments and polysaccharides [37]. However, the structure of bromelain means that few organic solvents are well tolerated by the enzymes in the extract [38]. Using this method Sankaran et al. have obtained pure bromelain with significant protease activity (stem: 4.0 units / mg; fruit: 3.6 units $/ \mathrm{mg}$ ) when a mix of polyethylene glycol (PEG) (8\% w/w) and ammonium sulphate $(15 \% w / w)$ was used [39]. Similar results have been obtained using a PEG/potassium phosphate system [27].

Ketnawa et al. have used several biphasic systems, containing PEG and salts at different concentrations, to test the purification of bromelain from pineapple peel. The highest enzymatic activity and yield was obtained with PEG-3000 (15\% w/w) and magnesium sulphate $(20 \%)$ in water (enzyme activity: 5.23 units $/ \mathrm{mg}$ ) [40].

Finally, an aqueous two-phase system used to extract and purify bromelain with polyphenol oxidase provided a four-fold concentration from the starting material [27].

\section{(B). Chromatographic techniques}

Ion exchange chromatography is one of the most commonly employed of the chromatographic methods used for bromelain extraction, and has proven to be a low-cost, highly specific, scalable and reliable technique [41]. Cation exchange chromatography has been used to separate ananain in combination with affinity chromatography [42]. However, better purification (85\% of the initial active proteases) has been obtained using acetone precipitation in combination with the two above-mentioned chromatographic techniques [17]. 
Bresolin et al. have demonstrated the efficacious separation of the enzymatic complex from polysaccharides using ion exchange chromatography (removal of $97.7 \%$ of the polysaccharides initially present in the crude extract) [8].

Devakate et al. have separately employed salt precipitation and ionic exchange chromatography to extract bromelain from clarified pineapple juice. The latter technique led to a 10-fold enrichment in bromelain (from 58 to 590 units/mg) and gave a threefold higher yield than salt precipitation [35]. A bromelain preparation with comparable enzymatic activity ( 390 units $/ \mathrm{mg}$ ) has been obtained by Costa et al. using a combination of cation exchange and size exclusion chromatography [11]. Hernández et al. have also tested the combination of cation exchange and size exclusion chromatography, and this approach resulted in the recovery of $41.15 \%$ of enzymatic activity, in relation to the initial stem extract [43].

Affinity chromatography is another successful technique for bromelain extraction. Bobb et al. have managed to isolate stem bromelain from other impurities by eluting pineapple-stem extracts through agarose- $\varepsilon$-aminocaproyl-D-tryptophan methyl ester (ACTME) [44]. Similar results have been obtained by Rowan et al. using a SepharoseAhx-Phe-GlySc column [17]. The effective separation of recombinant bromelain has also been performed using a different type of affinity chromatography, based on a nickel ligand (Ni-NTA His Bind resin) [25]. Indeed, Amid et al. obtained an increased purity grade (41-fold) for the recombinant bromelain expressed in the BL21-AI E. coli strain using this method [45].

High-speed counter-current chromatography has been tested by Yin et al. in combination with a reverse-micelle solvent system to purify bromelain; $3.0 \mathrm{~g}$ of bromelain was generated from $5 \mathrm{~kg}$ of pineapple fruit [46].

\section{(C). Reversed micellar extraction}

Reversed micellar extraction (RME) is a feasible, relatively low-cost and energyefficient process that is simple to scale-up and is characterized by protein solubilisation towards micellar inner polar cores. This technique can selectively separate enzymes and proteins such as those contained in the raw bromelain extract. This method involves two steps named forward and backward extraction; the first is a selective solubilization of proteins into reverse micelles and the second is the release of proteins from the micelles to an aqueous phase. Chaurasiva et al. have reported a recovery of $85 \%$ (four-fold purification) of bromelain using this approach [47]. Hebbar et al. have obtained significant bromelain recovery using small-scale $(10 \mathrm{~mL})$ RME purification methodologies. Similar results have been obtained at a larger scale, although a small loss in bromelain recovery was observed [48].

\section{(D). Precipitation methods}

Precipitation is a technique that is based on the addition of a range of precipitating agents: (1) salts, (2) non-ionic polymers, (3) organic solvents (ethanol, propanol, methanol, ketones, etc.). An alternative method is based on $\mathrm{pH}$ change, which alters the nature of the solution.

Organic solvents have been used successfully for bromelain purification. In fact, ethanol (30-70\%) has been used for extraction, leading to a recovery of $98 \%$ of the initial enzymatic activity [9]. Ethanolic extraction gave higher yields than sulphate and isoelectric precipitation [49]. Soares et al. have compared different precipitation agents; ethanol, (NH4)2SO4, and PEG. The most effective agent was ethanol, which gave higher enzyme recovery $(30-70 \%$ vs. $20-40 \%)$ than ammonium sulphate, whereas PEG failed to precipitate bromelain [9].

These methods have also been extensively combined with other purification techniques (e.g., chromatography) to remove impurities and contaminants, as well as to improve enzyme purity and specific activity $[5,8,20,35]$.

\section{(E). Novel strategies with recombinant technologies}


Recombinant DNA technology is a well-known methodology used to produce about $90 \%$ of the enzymes on the market as a whole [50]. The production of recombinant cysteine proteases, such as papain from Pichia pastoris [50] and glycyl endopeptidase from E. coli [51], has been reported in the literature. The first attempt to obtain recombinant bromelain was carried out by Jung et al. who cloned the BAA1 gene that encodes fruit bromelain in Brassica rapa [51]. The stem-bromelain gene, from Ananas comosus, has been cloned by Muntari et al. and gave higher enzymatic activity than commercial bromelain, with the optimum temperature and $\mathrm{pH}$ being $45^{\circ} \mathrm{C}$ and 4.6, respectively [50]. Recombinant bromelain from Ananas comosus showed higher thermal stability, as highlighted in a study by Nurul et al. [52]. Recombinant stem bromelain also showed higher potential as an anti-microbial agent (in particular vs. E. coli O111), compared to the commercial product [53].

Table 2. Unconventional techniques for the extraction and purification of bromelain (adapted from Manzoor et al., 2016 [54]).

\begin{tabular}{|c|c|c|c|c|}
\hline & Purification Technique & $\begin{array}{c}\text { Activity } \\
\text { Recovery (\%) }\end{array}$ & $\begin{array}{l}\text { Purification } \\
\text { Fold/Factor }\end{array}$ & Reference \\
\hline \multirow{5}{*}{$\begin{array}{l}\text { Aqueous two-phase } \\
\text { extraction }\end{array}$} & $\mathrm{PEG} / \mathrm{K}_{2} \mathrm{SO}_{4}$ & 228 & 4.0 & [27] \\
\hline & PEG/polyacrylic acid & 335.27 & 25.78 & [55] \\
\hline & $\mathrm{PEG} /\left(\mathrm{NH}_{4}\right)_{2} \mathrm{SO}_{4}$ & - & 11.80 & {$[38]$} \\
\hline & $\mathrm{PEG} / \mathrm{MgSO}_{4}$ & 113.54-206 & $2.23-62$ & {$[10,39,56,57]$} \\
\hline & Block copolymers & 79.5 & 1.25 & [36] \\
\hline \multirow{3}{*}{ Filtration } & Microfiltration and ultrafiltration & $85-100$ & 10 & [32] \\
\hline & $\begin{array}{l}\text { Microfiltration, ammonium sulphate } \\
\text { precipitation, ultracentrifugation }\end{array}$ & 50 & - & {$[30]$} \\
\hline & Nano-TiO ${ }_{2}$, ultrafiltration & 64.75 & 5.3 & {$[31]$} \\
\hline \multirow{2}{*}{$\begin{array}{l}\text { Reverse micellar } \\
\text { systems }\end{array}$} & Reverse micelle systems & $85-97.56$ & $4-5.2$ & {$[45,46,48,58]$} \\
\hline & Affinity-based reverse micelle system & 185.6 & 12.32 & [59] \\
\hline \multirow{4}{*}{ Chromatography } & $\begin{array}{l}\text { High speed counter-current } \\
\text { chromatography, reverse micelle system }\end{array}$ & - & - & [45] \\
\hline & Immobilized metal affinity membrane & 94.6 & 15.4 & [60] \\
\hline & Precipitation, ion exchange chromatography & - & 3.3 & [35] \\
\hline & Cation exchange chromatography & - & 10 & [61] \\
\hline
\end{tabular}

\subsection{Comparison of Bromelain Extraction Techniques}

The direct comparison of the published data on bromelain extraction techniques is a difficult task because several types of bromelain extracts and test conditions were used. Purification level and activity are the two main parameters used to assess the differences between extraction techniques (Table 3). The aqueous two-phase extraction technique showed the highest purification factor even if it involved a strong reduction in enzymatic activity [62]. Moreover, despite this strategy being considered a rapid and scalable technique, one of the main disadvantages of this process is the high salt concentration and the critical recovery that hamper recycling. Precipitation has a high activity recovery, second only to ultrafiltration, in addition to being a low-cost technique and, for this reason, the most used for commercial bromelain extracts. Nevertheless, the purification fold with this method is generally low and it presents the same problem as the aqueous two-phase extraction technique of high precipitant content (waste environmental impact) [20]. Ion exchange chromatography is the most expensive technique for several reasons: the low recovery and separation efficiency, and the small sample loading capacity [35]. However, it can produce satisfactory results especially when combined with other techniques such as gel filtration. In this regard, one of the challenges for the coming years is the study of new 
hybrid extraction techniques to optimize costs, reduce environmental impact and increase extract yield and purity. Limited information is available for the use of affinity membranes, despite the fact that the potentially high selectivity could represent an important advantage for bromelain extraction [63]. Lastly, the ultrafiltration technique seems to be the most promising for bromelain large-scale extraction operation because it is easily scalable to high product throughput and environmentally friendly [32]. To date, the most promising and economically viable results have been obtained by combining different processes such as the reverse micellar systems with ultrafiltration [33] or microfiltration prior to ultrafiltration [64].

Table 3. Comparison of the different bromelain separation techniques.

\begin{tabular}{ccccc}
\hline Separation Method & $\begin{array}{c}\text { Purification } \\
\text { Fold }\end{array}$ & $\begin{array}{c}\text { Activity } \\
\text { Recovery (\%) }\end{array}$ & Advantages & Limitations \\
\hline $\begin{array}{c}\text { Aqueous two-phase } \\
\text { extraction }\end{array}$ & 16.3 & 55.6 & $\begin{array}{c}\text { Aqueous medium } \\
\text { Low cost }\end{array}$ & $\begin{array}{c}\text { Poor knowledge on } \\
\text { mechanisms; High salt } \\
\text { content }\end{array}$ \\
\hline $\begin{array}{c}\text { Ion exchange } \\
\text { chromatography }\end{array}$ & 10 & 84.5 & Mild operation condition & $\begin{array}{c}\text { High cost; Difficult } \\
\text { optimization due to the } \\
\text { complexity }\end{array}$ \\
\hline $\begin{array}{c}\text { Precipitation } \\
\text { [62] }\end{array}$ & 4.9 & 85.97 & $\begin{array}{c}\text { Low energy needed } \\
\text { Many alternative as } \\
\text { precipitants }\end{array}$ & $\begin{array}{c}\text { High precipitant (salt) } \\
\text { content, hardly } \\
\text { reciclable }\end{array}$ \\
\hline Ultrafiltration & 10 & 90 & $\begin{array}{c}\text { High product throughput } \\
\text { Environmentally friendly } \\
\text { Easy scaling up }\end{array}$ & $\begin{array}{c}\text { Membrane fouling } \\
\text { [20] }\end{array}$ \\
\hline Affinity membranes & 2.5 & - & High selectivity & $\begin{array}{c}\text { High costs and difficult } \\
\text { monitoring }\end{array}$ \\
\hline
\end{tabular}

\section{Bromelain Enzymatic Activity Measurement}

The detection of the enzymatic activity of the various bromelain extracts and preparations is fundamental to assessing their bromelain content, which reflects the yield efficiency of the extraction and purification techniques, as well as the stability of the proteolytic activity under operational and storage conditions ( $\mathrm{pH}$, temperature). A number of different substrates can be used to measure bromelain activity, ranging from casein, gelatin and hemoglobin to the more sensitive casein and albumin azo-derivatives and various artificial model peptides.

Casein, which can also be used in the form of sodium caseinate, is the most frequently used substrate for proteolytic activity measurements [65], due to its high availability and low cost. Proteolytic-activity measurements are usually performed on $0.5-1 \%$ casein solutions in buffers at neutral $\mathrm{pH}$ over various time periods, ranging from 5 to $30 \mathrm{~min}$, after which the reaction is stopped via the addition of trichloroacetic acid (TCA) $[9,35,40,48]$. The amount of soluble peptides released by bromelain is detected at $275-280 \mathrm{~nm}$ and usually compared with a standard curve obtained using tyrosine solutions at increasing concentrations to calculate the enzymatic activity. It is worth noting that thiol-based reducing agents and EDTA are required for the optimal measurement of enzymatic activity [66]. The reducing agents prevent the oxidation of catalytic cysteine, whereas the EDTA chelates metals that may interfere with the enzymatic activity $[67,68]$.

The proteolysis of azocasein (1\% solution in buffers at $\mathrm{pH} 6.5-7.5)$ results in the formation of peptides with histidine and tyrosine diazo sulphonic acid analogues that remain in solution after the reaction mixture is treated with 5-10\% TCA. Azo-derived soluble peptides can be detected spectrophotometrically at $440 \mathrm{~nm}$ after the addition of an alkali solution with no significant interference from other colored compounds $[8,19,55]$. Activity measurements are usually carried out at $37^{\circ} \mathrm{C}$, both in the case of casein and 
azo-casein, although a number of studies have reported that the optimum temperature for stem and fruit bromelain lies in the $50-60^{\circ} \mathrm{C}$ range [55].

Bromelain proteolytic activity can be conveniently measured using a number of synthetic substrates that simulate model peptides, which release molecules that are easily detectable by fluorescence and/or spectrophotometry. Although more expensive than the previously described substrates, Z-Arg-Arg-p-nitroaniline (pNA), Bz-Phe-Val-Arg-pNA, pGlu-Phe-Leu-p-nitroanilide and N-Cbz-L-Gln-p-nitrophenyl ester are widely used as they allow continuous measurements of enzymatic activity to be performed, with free pNA being detected at 400-410 nm [15,69-71]. The peculiar chemical structure of these synthetic compounds also facilitates the easy detection of bromelain sources, since the enzymes derived from the various plant parts have shown preferential hydrolytic activity towards these substrate types [15]. In particular, the Z-Arg-Arg substrate is specific for stem bromelain, whereas fruit bromelain and ananain have shown more preferential activity towards the Bz-Phe-Val-Arg substrate [15,72,73].

\section{Pharmacodynamics and Pharmacokinetics Profiles of Bromelain}

The mechanisms of action of bromelain have not yet been fully established. However, the anti-inflammatory activity of this supplement on three different pathways has been highlighted in several in vivo and in vitro studies. The first is the kallikrein-kinin pathway; bromelain regulates the plasma fibrinogen levels and blood levels of bradykinin and improves serum fibrinolytic activity by activating factor XI, which subsequently activates plasma prekallikrein [54,74]. Secondly, bromelain acts on the arachidonic acid pathway (Figure 2); it modulates proinflammatory prostaglandins (via the inhibition of prostaglandin E2 and thromboxane A2) and enhances the anti-inflammatory mediators, increasing platelet cyclic adenosine monophosphate (cAMP), and, thus, the levels of prostaglandin (PG) I2 and PGE1. Finally, bromelain modulates cell-migration immunity: acting on the migration of neutrophils to inflammation sites [75]. In detail, it removes several cell-surface molecules (including CD128a/CXCR1, CD128b/CXCR2, CD14, CD44, CD16 and CD21) that are vital to leukocyte trafficking, cellular adhesion, the induction of pro-inflammatory mediators and immunomodulatory effect on $\mathrm{T}$ cells. It also reduces P-selectin-mediated neutrophil recruitment (Figure 1) [76]. These actions permit bromelain to be potentially effective in several conditions associated with inflammation, with or without oedema, and alterations in blood coagulation. In fact, RCTs that have been carried out highlight the activity of bromelain in diseases such as rheumatoid arthritis, osteoarthritis, perioperative sport injuries, cancer, cardiovascular diseases, chronic rhinosinusitis and skin wounds and burns, which are all conditions with an inflammatory component [3].

The pharmacokinetics profile of bromelain is still unclear because of difficulties determining this component in serum and the poor knowledge of its bioaccessibility and bioavailability. It would appear that bromelain is absorbed into the small intestine, rapidly forming a complex with anti-proteases ( $\alpha 2$-macroglobulin and $\alpha 1$-trypsin) [7]. On the other hand, the possibility that bromelain penetrates the lamina propria intact has been underlined, with $\alpha 2$-macroglobulin-bromelain complexes being formed, leaving bromelain proteolytic activity untouched [15]. Bromelain is considered to be a safe nutraceutical. As reported by Moss et al., it is impossible to determine the LD50 (mg/kg body weight) of this supplement at doses above $10 \mathrm{~g} / \mathrm{kg}$ per os in mice, rats and rabbits. However, the LD50 for intraperitoneal administration is $37 \mathrm{mg} / \mathrm{kg}$ and $85 \mathrm{mg} / \mathrm{kg}$ for mice and rabbits respectively, while for intravenous administration it is $30 \mathrm{mg} / \mathrm{kg}$ and $20 \mathrm{mg} / \mathrm{kg}$ [77]. No relevant side effects have been observed at doses of up to $2000 \mathrm{mg} / \mathrm{Kg}$ per os, even with prolonged periods of administration [7]. However, although bromelain is well tolerated and considered a safe nutraceutical, clinical trials have reported a few side effects, including transitory diarrhea, nausea and vomiting, allergic reactions and a risk of bleeding, especially in people treated with anticoagulant drugs, such as warfarin and clopidogrel [78]. 
- Bradykinin (vascular permeability, pain)

- TXA-2 (vasoconstriction, platelet aggregation)

- PGE-2 (vasodilation)
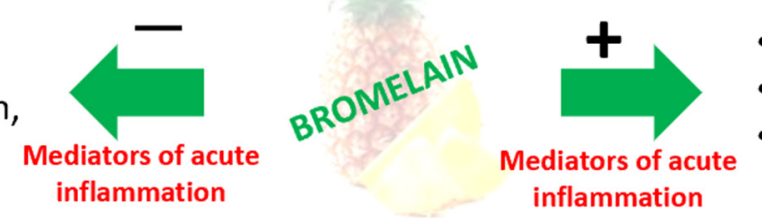

- TNF (leukocytes adhesion)

- IL-1 (leukocytes adhesion)

- PGI-2 (vasodilation, platelet inflammation aggregation)

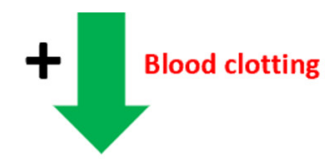

- Degradation of fibrin

- Prothrombin reduction

- Prekallikrein reduction

Figure 2. Bromelain anti-inflammatory and anticoagulant mechanisms of action.

\section{Bromelain Studies}

The clinical applications of bromelain include a wide range of conditions that are generally characterized by an inflammatory component that may be associated (or not) with oedema and alterations in blood coagulation. These therapeutic applications are discussed below and summarized in Figure 3 .

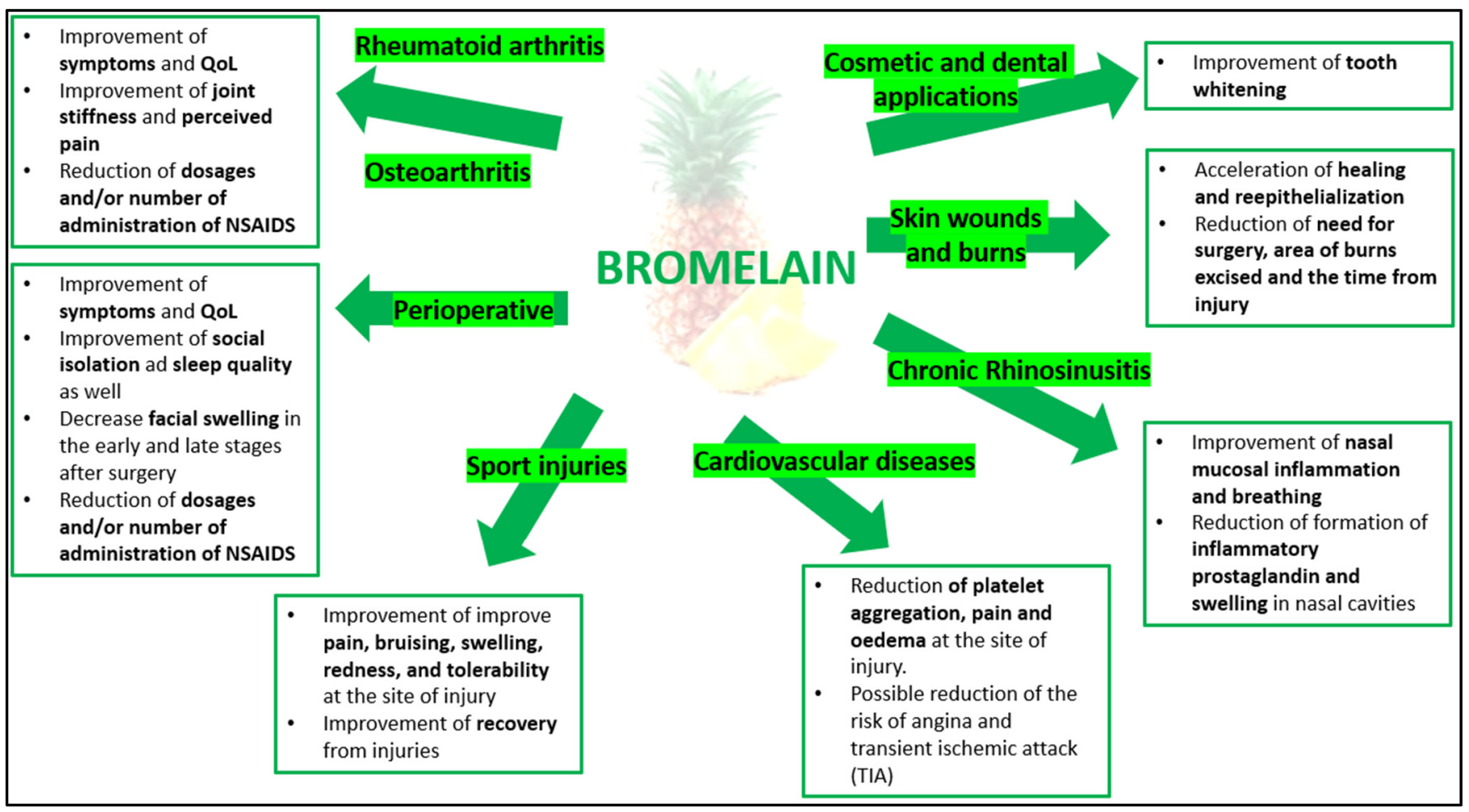

Figure 3. Bromelain and its potential clinical applications. 


\subsection{Perioperative}

A recent meta-analysis of six RCTs demonstrated that bromelain alleviates postoperative pain seven days after mandibular third molar surgery $(p=0.002)$ and decreases facial swelling in the early and late stages after surgery (respectively $p=0.02$ and $p=0.0004$ ) [79]. Similar results were obtained in previous meta-analyses carried out by Mendes et al. [80], de Almeida et al. [81] and de Souza et al. [82], that also showed improvements in social isolation and sleep quality.

In another RCT, sixty patients with long bone fractures were treated with $810 \mathrm{mg} /$ day bromelain for the first three days after surgery and $480 \mathrm{mg} /$ day in the remaining follow-up period, with the antioedematous drug aescin being used as the control. A significant decrease in post-traumatic and post-operative swelling and pain was observed in patients who were administered bromelain. Healing acceleration was also observed compared to the control group (to whom aescin was administered) [83].

In another RCT, eighty-two primiparous women were treated with bromelain and benefited from reductions in pain (measured on the VAS scale), ecchymosis and oedema caused by episiotomy compared with a placebo group $(p<0.05$ for all). In addition, wound healing was faster in the bromelain group than in the placebo group $(p<0.05)$ [84]. Howat et al. also demonstrated the existence of a trend of reduction in pain and ecchymosis, although the differences did not reach statistical significance [85].

Seltzer and colleagues reported the ability of bromelain to decrease perioperative oedema and ecchymosis in 53 rhinoplasty cases [86].

\subsection{Osteoarthritis and Rheumatoid Arthritis}

The anti-inflammatory and analgesic properties of bromelain were first reported in 1964 for the treatment of both osteoarthritis (OA) and rheumatoid arthritis [87]. Several RCTs underlined the potential ability of this nutraceutical to decrease pain and inflammation in people with knee and hip OA [88]. In one of the most recent RCTs, 16-week supplementation with bromelain (500 mg/day) and diclofenac (100 mg/day) was tested in mild-to-moderate knee OA patients. At the end of treatment, the effects of bromelain and diclofenac in mitigating the symptoms of mild-to-moderate knee OA were comparable [Western Ontario and McMaster Universities Osteoarthritis Index (WOMAC)] [89]. Similar results have been obtained in people with hip OA [81]. Another study included forty men and women with lumbar spine osteoarthritis who were divided into two groups to receive, for six weeks, either aceclofenac $100 \mathrm{mg}$ b.i.d or aceclofenac $100 \mathrm{mg}$ b.i.d with enzyme supplements (bromelain) $250 \mathrm{mg}$ b.i.d. The patients treated with bromelain reported significantly diminished pain scores (visual analogue scale and Oswestry low back pain questionnaire, respectively $p=0.001$ and $p=0.000$ ) and improved life quality, compared with patients treated with aceclofenac alone [90]. Bromelain's potent analgesic and antiinflammatory properties were highlighted when administrated to patients suffering from chronic osteoarthritis (both pain-associated and not), even when used in association with other nutraceuticals including Curcuma longa, Harpagophytum procumbens and/or Boswellia serrata [91]. Bromelain potentially acts as a non-steroidal anti-inflammatory drug (NSAIDS) painkiller, as it reduces the dosage and/or the number of administrations of conventional treatments [92].

\section{Sport Injuries}

In recent years, bromelain's properties have been tested in the treatment of sportrelated muscle injuries and in relieving occasional post-exercising muscle pain [93]. Muscle pain and apparent stiffness that is experienced after training (so-called "delayed onset muscle soreness" (DOMS)) is one of the most important limitations for athletes who perform repeated strenuous exercises [94]. In this regard, bromelain has been shown to attenuate the occurrence of contraction-induced skeletal muscle injury, which is considered to be one of the causes of DOMS [95]. However, in a recent study, forty subjects that were treated with either bromelain (300 $\mathrm{mg}$ t.i.d.), ibuprofen ( $400 \mathrm{mg}$ t.i.d.), placebo (t.i.d.) and a 
control group demonstrated no significant improvement in their active range of motion and perceived pain after an eccentric exercise protocol (bromelain and ibuprofen seem to be ineffective and comparable to the placebo) [96]. In addition, the supplementation of bromelain with rutoside before and after a marathon race failed to attenuate postrace inflammation, neither did it decrease the incidence of upper-respiratory illness in runners [97].

In a multicentre, double blind RCT involving 27 European hospitals, 721 patients with acute unilateral sprains of the lateral ankle joint were treated with a triple combination (bromelain, rutoside and trypsin), double combinations, single substances or a placebo. The results showed that bromelain had no remarkable impact on decreasing symptoms compared to either the double combinations and/or the other single substances. However, significant improvements in pain, swelling and range of motion were observed compared with the placebo [98]. In contrast to these results, patients with sport-related ankle injuries that were treated with bromelain in a double-blind placebo-controlled trial had faster recovery times than the control group [99]. Even the double-blind studies of Zuschlag [100], Deitrick [101] and Rathgeber [102] demonstrated significant improvements in healing from sports injuries and faster haematoma resorption.

Finally, bromelain treatment has been shown to improve pain, bruising, swelling, redness and tolerability at the site of injury when administrated to patients suffering from blunt trauma injuries to the musculoskeletal system [103]. Moreover, in subjects with haematoma, bromelain induced more rapid resorption with a significant decrease in haematoma volume compared to the placebo group [104].

\subsection{Acute Sinusitis, Rhinitis, Rhinosinusitis}

Bromelain also acts as a mucolytic agent, decreasing mucus production while promoting natural drainage, the formation of inflammatory prostaglandin and decreasing swelling in nasal cavities. Several trials have investigated the role of this supplement in sinusitis, rhinitis, rhinosinusitis and chronic rhinosinusitis, although there is a lack of long-term data $[105,106]$. Seltzer et al. have treated 49 patients affected by sinusitis with either bromelain or a placebo. In association with the conventional treatment, the bromelain group showed general improvements in overall rating, breathing difficulties and nasal discomfort [107]. Similar results have been obtained by Ryan et al. who observed that bromelain administration improved nasal mucosal inflammation and breathing in people with acute sinusitis [108]. Finally, the administration of bromelain (average intake: six tablets $=3000$ Fédération Internationale Pharmaceutique (FIP)) to 12 patients with chronic rhinosinusitis, both with and without nasal polyps, in a prospective, open-label, observational pilot study provided a significant improvement in total symptom scores (TSS), total rhinoscopy score (TRS) and quality of life (Sino-nasal Outcome Test 20) [98].

\subsection{Cancer}

In vitro and in vivo studies have demonstrated the anti-cancer effects of bromelain; it quite likely switches-off the NF-kB gene signal, thus inhibiting Cox-2 expression, activating several caspases and promoting apoptosis $[109,110]$. In addition, bromelain exhibits antimetastatic properties, which it exerts via the upregulation of p53 and the activation of the autophagy mechanism [67]. The potential effects of this supplement, in terms of tumorsize reduction and/or regression and improvements in chemotherapeutic-agent efficiency, have been highlighted in many studies carried out on several cell lines, including A-375 melanoma, P-388 leukemia, ADC-755 breast cancer, sarcoma (S-37), A431 epidermoid carcinoma and Lewis lung cancer [111-113]. Although there is a lack of RCTs to investigate the effects of bromelain on tumor progression, bromelain-related decreases in the side effects caused by conventional treatments have been evaluated by a number of research groups.

In a clinical investigation, 494 patients with breast cancer that were undergoing adjuvant hormone therapy and suffering from severe arthralgia as well as severe mucosal 
dryness were treated with a complementary adjuvant, which included bromelain in addition to papain, sodium selenite and Lens culinaris lectin. Two-thirds of patients showed an improvement in both arthralgia and mucosal dryness after four weeks, with the conventional treatments causing limited side effects $(p<0.001)$ [114]. Similar results have been obtained by the group of Uhlenbruck and colleagues [115]. Bromelain also stimulates the deficient monocytic cytotoxicity of mammary tumor patients [116] and promotes the apoptosis process [117].

Finally, bromelain supplementation, along with $\alpha$-lipoic acid, Boswellia serrata and methylsulfonylmethane, has been shown to decrease chemotherapy-induced peripheral neuropathy in patients treated with neurotoxic chemotherapy [118].

\subsection{Blood Coagulation and Cardiovascular Disease}

Bromelain is effective, as an adjuvant, in the treatment of cardiovascular diseases, especially as it is known to possess antithrombotic and anticoagulant activities [67], although clinical trials are, in part, conflicting and require further confirmation. Bromelain has been demonstrated to reduce platelet aggregation, as induced by adenosine phosphate, blood viscosity and the risk of thrombus formation, while also improving the phosphorylation of Akt, and thus inhibiting cell apoptosis [119]. In vivo studies have shown that bromelain decreases the risk of angina pectoris and transient ischemic attack (TIA), although longterm RCTs are required to confirm this preliminary evidence [2]. Furthermore, bromelain possesses antihypertensive properties [7]. It has been reported that the oral administration of bromelain significantly reduces the risk of acute thrombophlebitis $[2,120]$. On the other hand, bromelain supplementation did not significantly affect blood clotting in another clinical trial that included healthy volunteers [121]. Similar conclusions have been obtained in another trial in which supplementation with $160 \mathrm{mg} /$ day of bromelain (for one week in patients with oedema and inflammation) did not affect bleeding, coagulation and prothrombin [122]. These contradictory results might, in part, be explained by both the limited sample size and dosage of supplemented bromelain. In fact, Errasti and colleagues have highlighted the dual action of bromelain on blood coagulation; at low dosage, this supplement seems to have a pro-coagulant effect, while having an anticoagulant effect at a high dosage [123].

\subsection{Other Applications}

Bromelain is also an interesting nutraceutical for cosmetic dental applications, in particular for tooth whitening. In a recent study, tooth bleaching gels containing bromelain, used in association with papain, have been demonstrated to be potentially effective in the development of peroxide-free tooth whitening gels [124].

Bromelain, used in association with other active ingredients, has also been observed to increase the function of macular pre-ganglionic elements, as demonstrated in a recent RCT that included thirty patients with intermediate age-related macular degeneration [125].

In a multi-center, open-label, non-comparative clinical trial, 398 women with endometriosis-associated pelvic pain were treated for six months with bromelain, $\mathrm{N}$ acetyl cysteine and alpha lipoic acid. The treatment provided a significant improvement in endometriosis-associated pelvic pain (visual analogue scale $>4$ diminished from $92.7 \%$ to $82.7 \%(p<0.05))[126]$.

Bromelain supplementation in people with inflammatory bowel disease is another potential indicator of its efficacy. Although new RCTs are urgently needed to better understand the effects of bromelain on the prevalence, severity and sternness of colitis, quality of life and markers of inflammation, this supplement decreased the harshness of colonic inflammation. This effect is probably due to its proteolytic action, which most likely eradicates the cell-surface receptors involved in leukocyte defection and activation [127].

Bromelain has also shown relevant activity in allergic airway diseases [128], decreasing the serum levels of interleukins (IL)-4, $-12,-13,-17$ and interferon-alpha, bronchoalveolar lavage leukocytes (eosinophils and lymphocytes), cellular infiltrates and bronchoalveolar 
lavage CD4+, CD8+ T CD4+ and CD25+T cells [129]. However, there is also a lack of RCTs in this case.

Topical applications of bromelain have been tested for skin wounds, burns and the debridement of necrotic tissues [130]. Bromelain includes a specific fraction of escharase, which is considered to be the main debriding agent and can selectively act upon damaged tissues without harming healthy ones $[2,131]$. The escharase fraction has been demonstrated to accelerate healing and reepithelialization by simplifying the debridement process [132]. In a multi-center, open-label RCT, patients (4-55 years old) with deep partial and full thickness burns, covering 5-30\% of their total body surface area, were either treated with a topical application of bromelain (for $4 \mathrm{~h}$ ) or with the standard of care, which included either surgical excisional or non-surgical debridement. Treatment with bromelain significantly decreased the need for surgery, area of burns excised and the time from injury to complete debridement compared with standard care ( $p<0,0001$ for all) [133]. The updated guidelines of a multi-professional expert panel of plastic surgeons and burncare specialists recommended the use of bromelain as an enzymatic debriding agent for burns [134].

In a preliminary study, eight patients with pityriasis lichenoides chronica were treated with bromelain (40 mg three times a day for one month, $40 \mathrm{mg}$ twice a day for one month and $40 \mathrm{mg}$ a day for one month) and showed an improvement in the condition that can probably be traced to its anti-inflammatory, immunomodulatory and/or anti-viral properties [135].

Although bromelain supplementation seems to be effective in many diseases, some limitations should be emphasized. Firstly, the sample populations considered in the studies were small and heterogeneous, the treatment period was limited and the bromelain dosages and types of extracts used were extremely variable, even when administered for the same disease. In addition, only a single clinical trial is available for most of the conditions mentioned in the literature. Finally, few data on bromelain safety are available, especially for long-term treatment. For these reasons, new long-term RCTs are needed to allow the prescription of this supplement in clinical practice and shed light on the pharmacokinetic and pharmacodynamic profiles of this complex nutraceutical.

\section{Discussion and Future Perspectives}

Bromelain is one of the most thoroughly investigated proteolytic complexes that is characterized by several thiol endopeptidases [136]. As discussed in this review, bromelain is extracted predominantly from pineapple stems and fruit [53]. However, a number of studies have underlined the possibility that bromelain can be extracted from by-products, such as the peels, core or crown, which would fulfil the requirements of a zero-waste approach [3].

Several studies have been carried out to evaluate the stability, purification and potential applications of bromelain, especially in the pharmaceutical and nutraceutical sectors $[5,137]$. While bromelain has been demonstrated to improve several conditions, thanks to its anti-inflammatory and anti-oedema properties, its mechanisms of action are yet to be completely understood [113].

Extraction techniques for bromelain include both conventional and unconventional methods (Table 4), which can also be combined in some cases [1]. Alternative methods for bromelain purification can be applied to achieve improved cost-effectiveness, purity and yields. In fact, one of the most important limitations to bromelain commercialization is the high cost of the extract (about $2400 \mathrm{USD} / \mathrm{Kg}$ ), which is mainly due to the required purification processes [12]. Although unconventional technologies, such as chromatography, reverse micellar systems, gel filtration, aqueous two-phase systems and others, have been thoroughly investigated and demonstrated to improve purity and yield, compared with conventional techniques, none have presented an economic assessment of the processes involved. Moreover, there is still a lack of standardized international guidelines for bromelain extraction. 
One of the most promising current strategies involves the production and purification of recombinant bromelain, which may decrease the overall process cost and improve bromelain yield and purity [50].

Considering the great medical and industrial interest in bromelain, future studies on convenient and effective extraction and purification techniques, the drafting of new international guidelines, an extensive costs analysis and the evaluation of process scalingup are necessary and are a challenge that may decrease production steps and costs. In the clinical setting, new pharmacodynamics and pharmacokinetics studies are needed to better understand the potential applications of this nutraceutical in terms of efficacy and safety.

Table 4. Advantages and limits of bromelain purification using classic or unconventional methods.

\begin{tabular}{|c|c|c|c|}
\hline Purification Approach & Technique & Advantages & Limits \\
\hline Classic methods & $\begin{array}{l}\text { Centrifugation } \\
\text { Ultrafiltration } \\
\text { Lyophilisation }\end{array}$ & $\begin{array}{c}\uparrow \text { yield during } \\
\text { pre-purification steps }\end{array}$ & $\downarrow$ enzymatic yields \\
\hline Unconventional methods & $\begin{array}{l}\text { Gel filtration } \\
\text { Ion exchange chromatography } \\
\text { Affinity chromatography } \\
\text { Aqueous two-phase extraction } \\
\text { Reversed micelle extraction }\end{array}$ & $\begin{array}{c}\uparrow \text { selectivity and purity of the } \\
\text { final extract } \\
\uparrow \text { enzymatic yields } \\
\downarrow \text { number of processes for } \\
\text { final bromelain extract } \\
\uparrow \text { efficacy of bromelain } \\
\text { purification }\end{array}$ & $\begin{array}{c}\uparrow \text { costs of product recovery } \\
\text { stability (?) }\end{array}$ \\
\hline
\end{tabular}

\section{Conclusions}

Bromelain extract is an interesting nutraceutical to be potentially used as an adjuvant in several conditions, including cardiovascular diseases, skin disorders, sport injuries, sinusitis and inflammatory diseases. However, the poor quality of clinical studies and the high cost of bromelain extraction and purification represent the main limitations to the use of these extracts. In this regard, new comprehensive studies are needed to validate the efficacy and safety of clinical applications and long-term RCTs must be designed before therapeutical recommendations. Further investigations of the mechanisms of action are also required. In addition, despite the broad array of studies on the applications of unconventional extraction methods, there is still a lack of guidelines for the processing steps required to obtain the highest yields and enzymatic activity.

Finally, new studies on the same matrices, comparing classic and non-conventional techniques or their combination, are also needed to optimize extract yield and activity, which may lead to an economically viable product.

Author Contributions: Conceptualization, A.C., S.A. and G.C.; literature search A.C., M.M. and S.L.; writing-original draft preparation, A.C. and S.L.; writing-review and editing, S.A. and G.C.; supervision, G.C. All authors have read and agreed to the published version of the manuscript.

Funding: This research was funded by the University of Turin and by the Ministry of Science and Higher Education of the Russian Federation: World-Class Research Center, Sechenov First Moscow State Medical University.

Informed Consent Statement: Not applicable.

Data Availability Statement: Not applicable.

Acknowledgments: This work was carried out under the auspices of the University of Turin (Ricerca Locale 2020) and the Ministry of Science and Higher Education of the Russian Federation (WorldClass Research Centers agreement № 075-15-2020-926).

Conflicts of Interest: The authors declare no conflict of interest. 


\section{References}

1. de Lencastre Novaes, L.C.; Jozala, A.F.; Lopes, A.M.; de Carvalho Santos-Ebinuma, V.; Mazzola, P.G.; Pessoa Junior, A. Stability, purification, and applications of bromelain: A review. Biotechnol. Prog. 2016, 32, 5-13. [CrossRef]

2. Pavan, R.; Jain, S.; Kumar, A. Properties and Therapeutic Application of Bromelain: A Review. Biotechnol. Res. Int. 2012, 2012, 1-6. [CrossRef]

3. Ramli, A.N.M.; Aznan, T.N.T.; Illias, R.M. Bromelain: From production to commercialisation. J. Sci. Food Agric. 2017, 97, 1386-1395. [CrossRef]

4. González-Rábade, N.; Badillo-Corona, J.A.; Aranda-Barradas, J.S.; del Carmen Oliver-Salvador, M. Production of plant proteases in vivo and in vitro-A review. Biotechnol. Adv. 2011, 29, 983-996. [CrossRef] [PubMed]

5. Arshad, Z.I.M.; Amid, A.; Yusof, F.; Jaswir, I.; Ahmad, K.; Loke, S.P. Bromelain: An overview of industrial application and purification strategies. Appl. Microbiol. Biotechnol. 2014, 98, 7283-7297. [CrossRef]

6. Silveira, E.; Souza, M.E.; Santana, J.C.C.; Chaves, C.; Porto, A.L.F.; Tambourgi, E.B. Expanded bed adsorption of bromelain (E.C. 3.4.22.33) from Ananas comosus crude extract. Braz. J. Chem. Eng. 2009, 26, 149-157. [CrossRef]

7. Maurer, H. Bromelain: Biochemistry, pharmacology and medical use. Cell. Mol. Life Sci. 2001, 58, 1234-1245. [CrossRef] [PubMed]

8. Bresolin, I.; Bresolin, I.; Silveira, E.; Tambourgi, E.B.; Mazzola, P.G. Isolation and purification of bromelain from waste peel of pineapple for therapeutic application. Braz. Arch. Biol. Technol. 2013, 56, 971-979. [CrossRef]

9. Soares, P.A.; Vaz, A.F.; Correia, M.T.; Pessoa, A.; Carneiro-Da-Cunha, M.G. Purification of bromelain from pineapple wastes by ethanol precipitation. Sep. Purif. Technol. 2012, 98, 389-395. [CrossRef]

10. Ketnawa, S.; Chaiwut, P.; Rawdkuen, S. Aqueous Two-phase Extraction of Bromelain from Pineapple Peels ('PhuLae' cultv.) and Its Biochemical Properties. Food Sci. Biotechnol. 2011, 20, 1219-1226. [CrossRef]

11. Costa, H.B.; Fernandes, P.M.; Romao, W.; Ventura, J.A. A new procedure based on column chromatography to purify bromelain by ion exchange plus gel filtration chromatographies. Ind. Crop. Prod. 2014, 59, 163-168. [CrossRef]

12. Muntari, B.; Ismail, N.A.; Mel, M.; Jami, M.S.; Salleh, H.M.; Amid, A. Bromelain production: Current trends and perspective. Arch. Des Sci. 2012, 65, 369-399.

13. Ahmad, B.; Ansari, M.A.; Sen, P.; Khan, R.H. Low versus high molecular weight poly(ethylene glycol)-induced states of stem bromelain at low pH: Stabilization of molten globule and unfolded states. Biopolymers 2006, 81, 350-359. [CrossRef] [PubMed]

14. Ritonja, A.; Rowan, A.D.; Buttle, D.J.; Rawlings, N.; Turk, V.; Barrett, A. Stem bromelain: Amino acid sequence and implications for weak binding of cystatin. FEBS Lett. 1989, 247, 419-424. [CrossRef]

15. Rowan, A.D.; Buttle, D.J. Pineapple cysteine endopeptidases. Methods Enzymol. 1994, 244, 555-568. [CrossRef]

16. Hale, L.P.; Greer, P.K.; Trinh, C.T.; James, C.L. Proteinase activity and stability of natural bromelain preparations. Int. Immunopharmacol. 2005, 5, 783-793. [CrossRef]

17. Rowan, A.D.; Buttle, D.J.; Barrett, A. The cysteine proteinases of the pineapple plant. Biochem. J. 1990, 266, 869-875. [PubMed]

18. Khan, R.H.; Rasheedi, S.; Haq, S.K. Effect of pH, temperature and alcohols on the stability of glycosylated and deglycosylated stem bromelain. J. Biosci. 2003, 28, 709-714. [CrossRef] [PubMed]

19. Bhattacharya, R.; Bhattacharyya, D. Preservation of natural stability of fruit "bromelain" from Ananas comosus (pineapple). J. Food Biochem. 2009, 33, 1-19. [CrossRef]

20. Chaurasiya, R.S.; Hebbar, H.U. Extraction of bromelain from pineapple core and purification by RME and precipitation methods. Sep. Purif. Technol. 2013, 111, 90-97. [CrossRef]

21. Murachi, T. Bromelain enzymes. In Methods in Enzymology; Elsevier: New York, NY, USA, 1976; Volume 45, pp. 475-485. [CrossRef]

22. Bartholomew, D.P.; Paull, R.E.; Rohrbach, K.G. The Pineapple: Botany, Production, and Uses; CABI Publishing: New York, NY, USA, 2002.

23. Grabowska, E.; Eckert, K.; Fichtner, I.; SchulzeForster, K.; Maurer, H. Bromelain proteases suppress growth, invasion and lung metastasis of B16F10 mouse melanoma cells. Int. J. Oncol. 1997, 11, 243-248. [CrossRef]

24. Gautam, S.; Mishra, S.; Dash, V.; Goyal, A.K.; Rath, G. Comparative study of extraction, purification and estimation of bromelain from stem and fruit of pineapple plant. Thai J. Pharm. Sci. 2010, 34, 67-76.

25. Muntari, B.; Salleh, H.M.; Amid, A.; Mel, M.; Jami, M.S. Recovery of recombinant bromelain from Escherichia coli BL21-AI. Afr. J. Biotechnol. 2011, 10, 18829-18832.

26. Mulyono, N.; Rosmeilia, E.; Moi, J.G.P.; Valentine, B.O.; Suhartono, M.T. Quantity and quality of Bromelain in Some Indonesian Pineapple Fruits. Int. J. Appl. Biol. Pharm. 2013, 4, 235-240.

27. Babu, B.R.; Rastogi, N.; Raghavarao, K. Liquid-liquid extraction of bromelain and polyphenol oxidase using aqueous two-phase system. Chem. Eng. Process. Process. Intensif. 2008, 47, 83-89. [CrossRef]

28. Szymczyk, A.; Labbez, C.; Fievet, P.; Vidonne, A.; Foissy, A.; Pagetti, J. Contribution of convection, diffusion and migration to electrolyte transport through nanofiltration membranes. Adv. Colloid Interface Sci. 2003, 103, 77-94. [CrossRef]

29. Braeken, L.; Bettens, B.; Boussu, K.; Van Der Meeren, P.; Cocquyt, J.; Vermant, J.; Van Der Bruggen, B. Transport mechanisms of dissolved organic compounds in aqueous solution during nanofiltration. J. Membr. Sci. 2006, 279, 311-319. [CrossRef]

30. Doko, B.; Bassani, V.; Casadebaig, J.; Cavailles, L.; Jacob, M. Preparation of proteolytic enzyme extracts from Ananascomosus L. Merr. fruit juice using semi permeable membrane, ammonium sulfate extraction, centrifugation and freeze-drying processes. $J$. Immunopharmacol. 2005, 4, 783-795. 
31. Chao, M.A.; Wu, M.Y.; Qiao, X.; Song, Y.; Zhao, Y. Study on purification of stem bromelain by nano-TiO 2 and ultrafiltration. Food Sci. Technol. 2009, 34, 167-170.

32. Lopes, F.L.G.; Júnior, J.B.S.; De Souza, R.R.; Ehrhardt, D.D.; Santana, J.; Tambourgi, E.B. Concentration by membrane separation processes of a medicinal product obtained from pineapple pulp. Braz. Arch. Biol. Technol. 2009, 52, 457-464. [CrossRef]

33. Hebbar, U.H.; Sumana, B.; Hemavathi, A.B.; Raghavarao, K.S.M.S. Separation and Purification of Bromelain by Reverse Micellar Extraction Coupled Ultrafiltration and Comparative Studies with Other Methods. Food Bioprocess Technol. 2012, 5, $1010-1018$. [CrossRef]

34. Wang, W. Lyophilization and development of solid protein pharmaceuticals. Int. J. Pharm. 2000, 203, 1-60. [CrossRef]

35. Devakate, R.; Patil, V.; Waje, S.; Thorat, B. Purification and drying of bromelain. Sep. Purif. Technol. 2009, 64, 259-264. [CrossRef]

36. Rabelo, A.P.B.; Tambourgi, E.B.; Pessoa, A. Bromelain partioning in twophase aqueous systems containing PEO-PPO-PEO block copolymers. J. Chromatogr. B 2004, 807, 61-68. [CrossRef] [PubMed]

37. Gupta, R.; Bradoo, S.; Saxena, R.K. Aqueous two-phase systems: An attractive technology for downstream processing of biomolecules. Curr. Sci. 1999, 77, 520-523.

38. Coelho, D.F.; Silveira, E.; Junior, A.P.; Tambourgi, E.B. Bromelain purification through unconventional aqueous two-phase system (PEG/ammonium sulphate). Bioprocess Biosyst. Eng. 2013, 36, 185-192. [CrossRef] [PubMed]

39. Sankaran, K.; Vadanasundari, V.; Hemavathy, R.V. A Comparative Study on Determining the Efficacy of Salt Precipitation and Biphasic System in the Extraction of Bromelain from Ananas comosus. Asian J. Sci. Technol. 2011, 2, 16-22.

40. Ketnawa, S.; Sai-Ut, S.; Theppakorn, T.; Chaiwut, P.; Rawdkuen, S. Partitioning of bromelain from pineapple peel (Nang Laecultv.) by aqueous two phase system. Asian J. Food Agro-Ind. 2009, 2, 457-468.

41. Ng, P.K.; He, J.; Synder, M.K. Separation of proteins mixtures using PH-gradient cation exchange chromatography. J. Chromatogr. A 2009, 1216, 1372-1376. [CrossRef] [PubMed]

42. Rowan, A.D.; Buttle, D.J.; Barrett, A. Ananain: A novel cysteine proteinase found in pineapple stem. Arch. Biochem. Biophys. 1988, 267, 262-270. [CrossRef]

43. Hernández, M.; Carvajal, C.; Márquez, M.; Báez, R.; Morris, H.; Santos, R.; de los Ángeles Chávez, M. Obtención de Preparados Enzimáticos a Partir de Tallos de Piña (Ananas Comosus) con Potencialidades de uso en la Biotecnología y la Medicina. Rev. CENIC Cienc. Biológicas 2005, 36.

44. Bobb, D. Isolation of Stem Bromelain by Affinity Chromatography and its Partial Characterization by Gel Electrophoresis. Prep. Biochem. 1972, 2, 347-354. [CrossRef]

45. Amid, A.; Ismail, N.A.; Yusof, F.; Mohd-Salleh, H. Expression, purification, and characterization of a recombinant stem bromelain from Ananas comosus. Process Biochem. 2011, 46, 2232-2239. [CrossRef]

46. Yin, L.; Sun, C.; Han, X.; Xu, L.; Xu, Y.; Qi, Y.; Peng, J. Preparative purification of bromelain (EC 3.4.22.33) from pineapple fruit by high-speed counter-current chromatography using a reverse-micelle solvent system. Food Chem. 2011, 129, 925-932. [CrossRef]

47. Chaurasiya, R.S.; Sakhare, P.Z.; Bhaskar, N.; Hebbar, H.U. Efficacy of reverse micellar extracted fruit bromelain in meat tenderization. J. Food Sci. Technol. 2014, 52, 3870-3880. [CrossRef]

48. Hebbar, H.U.; Sumana, B.; Raghavarao, K. Use of reverse micellar systems for the extraction and purification of bromelain from pineapple wastes. Bioresour. Technol. 2008, 99, 4896-4902. [CrossRef]

49. Silvestre, M.P.C.; Carreira, R.L.; Silva, M.R.; Corgosinho, F.C.; Monteiro, M.R.P.; Morais, H.A. Effect of pH and Temperature on the Activity of Enzymatic Extracts from Pineapple Peel. Food Bioprocess Technol. 2012, 5, 1824-1831. [CrossRef]

50. Muntari, B.; Amid, A.; Mel, M.; Jami, M.S.; Salleh, H.M. Recombinant bromelain production in Escherichia coli: Process optimization in shake flask culture by response surface methodology. AMB Express 2012, 2. [CrossRef] [PubMed]

51. Jung, Y.-J.; Choi, C.-S.; Park, J.-H.; Kang, H.-W.; Choi, J.-E.; Nou, I.-S.; Lee, S.Y.; Kang, K.-K. Overexpression of the pineapple fruit bromelain gene (BAA) in transgenic Chinese cabbage (Brassica rapa) results in enhanced resistance to bacterial soft rot. Electron. J. Biotechnol. 2008, 11, 71-79. [CrossRef]

52. Nurul, A.; Azura, A. Differential scanning calorimetry as tool in observing thermal and storage stability of recombinant bromelain. Int. Food Res. J. 2012, 19, 727-731.

53. George, S.; Bhasker, S.; Madhav, H.; Nair, A.; Chinnamma, M. Functional Characterization of Recombinant Bromelain of Ananas comosus Expressed in a Prokaryotic System. Mol. Biotechnol. 2014, 56, 166-174. [CrossRef]

54. Manzoor, Z.; Nawaz, A.; Mukhtar, H.; Haq, I. Bromelain: Methods of Extraction, Purification and Therapeutic Applications. Braz. Arch. Biol. Technol. 2016, 59. [CrossRef]

55. Novaes, L.C.D.L.; Ebinuma, V.D.C.S.; Mazzola, P.G.; Júnior, A.P. Polymer-based alternative method to extract bromelain from pineapple peel waste. Biotechnol. Appl. Biochem. 2013, 60, 527-535. [CrossRef] [PubMed]

56. Ketnawa, S.; Rawdkuen, S.; Chaiwut, P. Two phase partitioning and collagen hydrolysis of bromelain from pineapple peel Nang Laecultivar. J. Biochem. Eng. 2010, 52, 205-211. [CrossRef]

57. Ferreira, J.F.; Santana, J.C.C.; Tambourgi, E.B. The effect of $\mathrm{pH}$ on bromelain partition from Ananascomosus by PEG4000/Phosphate ATPS. Braz. Arch. Biol. Technol. 2011, 54, 125-132. [CrossRef]

58. Navapara, R.D.; Avhad, D.N.; Rathod, V.K. Application of Response Surface Methodology for Optimization of Bromelain Extraction in Aqueous Two-Phase System. Sep. Sci. Technol. 2011, 46, 1838-1847. [CrossRef]

59. Kumar, S.; Hemavathi, A.B.; Hebbar, H.U. Affinity based reverse micellar extraction and purification of bromelain from pineapple (Ananascomosus L. Merryl) waste. Process Biochem. 2011, 46, 1216-1220. [CrossRef] 
60. Nie, H.; Li, S.; Zhou, Y.; Chen, T.; He, Z.; Su, S.; Zhang, H.; Xue, Y.; Zhu, L. Purification of bromelain using immobilized metal affinity membranes. J. Biotechnol. 2008, 136, S402-S459. [CrossRef]

61. Nadzirah, K.Z.; Zainal, S.; Noriham, A.; Normah, I. Efficacy of selected purification techniques for bromelain. Int. Food Res. J. 2013, 20, 43-46.

62. Wu, W.-C.; Ng, H.S.; Sun, I.-M.; Lan, J.C.-W. Single step purification of bromelain from Ananas comosus pulp using a polymer/salt aqueous biphasic system. J. Taiwan Inst. Chem. Eng. 2017, 79, 158-162. [CrossRef]

63. Zhang, H.; Nie, H.; Yu, D.-G.; Wu, C.; Zhang, Y.; White, C.J.B.; Zhu, L. Surface modification of electrospun polyacrylonitrile nanofiber towards developing an affinity membrane for bromelain adsorption. Desalination 2010, 256, 141-147. [CrossRef]

64. Nor, M.Z.M.; Ramchandran, L.; Duke, M.; Vasiljevic, T. Integrated ultrafiltration process for the recovery of bromelain from pineapple waste mixture. J. Food Process. Eng. 2017, 40, e12492. [CrossRef]

65. Corzo, C.A.; Waliszewski, K.N.; Welti-Chanes, J. Pineapple fruit bromelain affinity to different protein substrates. Food Chem. 2012, 133, 631-635. [CrossRef]

66. Murachi, T.; Neurath, H. Fractionation and Specificity Studies on Stem Bromelain. J. Biol. Chem. 1960, 235, 99-107. [CrossRef]

67. Giles, N.M.; Giles, G.; Jacob, C. Multiple roles of cysteine in biocatalysis. Biochem. Biophys. Res. Commun. 2003, 300, 1-4. [CrossRef]

68. Shukor, M.Y.; Masdor, N.; Baharom, N.A.; Jamal, J.A.; Abdullah, M.P.A.; Shamaan, N.A.; Syed, M.A. An inhibitive determination method for heavy metals using bromelain, a cysteine protease. Appl. Biochem. Biotechnol. 2008, 144, 283-291. [CrossRef] [PubMed]

69. Bala, M.; Mel, M.; Jami, M.S.; Amid, A.; Salleh, H.M. Kinetic studies on recombinant stem bromelain. Adv. Enzym. Res. 2013, 1, 52-60. [CrossRef]

70. Esti, M.; Benucci, I.; Liburdi, K.; Garzillo, A.M.V. Effect of Wine Inhibitors on Free Pineapple Stem Bromelain Activity in a Model Wine System. J. Agric. Food Chem. 2011, 59, 3391-3397. [CrossRef] [PubMed]

71. Filippova, I.; Lysogorskaya, E.; Oksenoit, E.; Rudenskaya, G.; Stepanov, V. 1-Pyroglutamyl-l-phenylalanyl-1-leucine-p-nitroanilideA chromogenic substrate for thiol proteinase assay. Anal. Biochem. 1984, 143, 293-297. [CrossRef]

72. Harrach, T.; Eckert, K.; Maurer, H.R.; Machleidt, I.; Machleidt, W.; Nuck, R. Isolation and characterization of two forms of an acidic bromelain stem proteinase. Protein J. 1998, 17, 351-361. [CrossRef]

73. Napper, A.D.; Bennett, S.P.; Borowski, M.; Holdridge, M.B.; Leonard, M.J.; Rogers, E.E.; Duan, Y.; Laursen, R.A.; Reinhold, B.; Shames, S.L. Purification and characterization of multiple forms of the pineapple-stem-derived cysteine proteinases ananain and comosain. Biochem. J. 1994, 301, 727-735. [CrossRef]

74. Tochi, B.N.; Wang, Z.; Xu, S.-Y.; Zhang, W. Therapeutic Application of Pineapple Protease (Bromelain): A Review. Pak. J. Nutr. 2008, 7, 513-520. [CrossRef]

75. Muhammad, Z.A.; Ahmad, T. Therapeutic uses of pineapple-extracted bromelain in surgical care-A review. J. Pak. Med Assoc. 2017, 67, 121-125. [PubMed]

76. Fitzhugh, D.J.; Shan, S.; Dewhirst, M.W.; Hale, L.P. Bromelain treatment decreases neutrophil migration to sites of inflammation. Clin. Immunol. 2008, 128, 66-74. [CrossRef]

77. Moss, J.N.; Frazier, C.V.; Martin, G.J. Bromelains: The Pharmacology of the Enzymes. Arch. Int. Pharmacodyn. Ther. 1963, 145, 166-189.

78. Hamdy, S. Bromelain. Monograph. Altern. Med. Rev. 2010, 15, 61-68.

79. Liu, S.; Zhao, H.; Wang, Y.; Zhao, H.; Ma, C. Oral Bromelain for the Control of Facial Swelling, Trismus, and Pain after Mandibular Third Molar Surgery: A Systematic Review and Meta-Analysis. J. Oral Maxillofac. Surg. 2019, 77, 1566-1574. [CrossRef]

80. Mendes, M.; Nascimento-Junior, E.D.; Reinheimer, D.; Martins-Filho, P. Efficacy of proteolytic enzyme bromelain on health outcomes after third molar surgery. Systematic review and meta-analysis of randomized clinical trials. Med. Oral Patol. Oral Cir. Bucal 2019, 24, e61-e69. [CrossRef] [PubMed]

81. Almeida, R.D.A.; Lima, F.D.S.; Vasconcelos, B.D.E. Is bromelain an effective drug for the control of pain and inflammation associated with impacted third molar surgery? Systematic review and meta-analysis. Int. J. Oral Maxillofac. Surg. 2019, 48, 651-658. [CrossRef] [PubMed]

82. De Souza, G.M.; Fernandes, I.A.; Dos Santos, C.R.R.; Falci, S.G.M. Is bromelain effective in controlling the inflammatory parameters of pain, edema, and trismus after lower third molar surgery? A systematic review and meta-analysis. Phytother. Res. 2019, 33, 473-481. [CrossRef] [PubMed]

83. Kamenícek, V.; Holán, P.; Franĕk, P. Systemic enzyme therapy in the treatment and prevention of post-traumatic and postoperative swelling. Acta Chir. Orthop. Traumatol. Cechoslov. 2001, 68, 45-49.

84. Golezar, S. Ananas comosus Effect on Perineal Pain and Wound Healing after Episiotomy: A Randomized Double-Blind Placebo-Controlled Clinical Trial. Iran. Red Crescent Med. J. 2016, 18, e21019. [CrossRef] [PubMed]

85. Howat, R.C.L.; Lewis, G.D. The Effect of Bromelain Therapy on Episiotomy Wounds-A Double Blind Controlled Clinical Trial. BJOG Int. J. Obstet. Gynaecol. 1972, 79, 951-953. [CrossRef]

86. Seltzer, A.P. Minimizing post-operative edema and ecchymoses by the use of an oral enzyme preparation (bromelain). A controlled study of 53 rhinoplasty cases. Eye Ear Nose Throat Mon. 1962, 41, 813-817. [PubMed]

87. Cohen, A.; Goldman, J. Bromelains Therapy in Rheumatoid Arthritis. Pa. Med. J. (1928) 1964, 67, 27-30.

88. Klein, G.; Kullich, W.; Schnitker, J.; Schwann, H. Efficacy and tolerance of an oral enzyme combination in painful osteoarthritis of the hip. A double-blind, randomised study comparing oral enzymes with non-steroidal anti-inflammatory drugs. Clin. Exp. Rheumatol. 2006, 24, 25-30. [PubMed] 
89. Kasemsuk, T.; Saengpetch, N.; Sibmooh, N.; Unchern, S. Improved WOMAC score following 16-week treatment with bromelain for knee osteoarthritis. Clin. Rheumatol. 2016, 35, 2531-2540. [CrossRef]

90. Naeem, H.; Naqvi, S.N.-U.; Perveen, R.; Ishaque, F.; Bano, R.; Abrar, H.; Arsalan, A.; Malik, N. Efficiency of proteolytic enzymes in treating lumbar spine osteoarthritis (low back pain) patients and its effects on liver and kidney enzymes. Pak. J. Pharm. Sci. 2020, 33, 371-378.

91. Conrozier, T.; Mathieu, P.; Bonjean, M.; Marc, J.-F.; Renevier, J.-L.; Balblanc, J.-C. A complex of three natural anti-inflammatory agents provides relief of osteoarthritis pain. Altern. Ther. Health Med. 2014, 20, 32-37.

92. Henriksson, K.; From, J.; Strateli, G. Patient-reported adherence to coprescribed proton pump inhibitor gastroprotection in osteoarthritis, rheumatoid arthritis, and ankylosing spondylitis patients using nonsteroidal anti-inflammatory drugs. Patient Prefer. Adherence 2014, 8, 1611-1617. [CrossRef]

93. Vital Produx. Enzymes for Athletic Injuries. Available online: http://www.vitalprodux.com/enzymes_for_athetic_injuries.html (accessed on 20 December 2001).

94. Hotfiel, T.; Freiwald, J.; Hoppe, M.W.; Lutter, C.; Forst, R.; Grim, C.; Bloch, W.; Hüttel, M.; Heiss, R. Advances in Delayed-Onset Muscle Soreness (DOMS): Part I: Pathogenesis and Diagnostics. Sportverletz. Sportschaden 2018, 32, 243-250. [CrossRef] [PubMed]

95. Walker, J.; Cerny, F.; Cotter, J. Attenuation of contraction induced skeletal muscle injury by bromelain. Med. Sci. Sports Exerc. 1992, 24, 20-25. [CrossRef] [PubMed]

96. Stone, M.B.; Merrick, M.A.; Ingersoll, C.D.; Edwards, J.E. Preliminary Comparison of Bromelain and Ibuprofen for Delayed Onset Muscle Soreness Management. Clin. J. Sport Med. 2002, 12, 373-378. [CrossRef]

97. Grabs, V.; Kersten, A.; Haller, B.; Braun, S.; Nieman, D.C.; Halle, M.; Scherr, J. Rutoside and Hydrolytic Enzymes Do Not Attenuate Marathon-Induced Inflammation. Med. Sci. Sports Exerc. 2017, 49, 387-395. [CrossRef]

98. Kerkhoffs, G.M.M.J.; Struijs, P.A.A.; De Wit, C.; Rahlfs, V.W.; Zwipp, H.; Van Dijk, C.N. A double blind, randomised, parallel group study on the efficacy and safety of treating acute lateral ankle sprain with oral hydrolytic enzymes. Br. J. Sports Med. 2004 38, 431-435. [CrossRef]

99. Baumuller, M. The application of hydrolytic enzymes in blunt woundsto the soft tissue and distortion of the ankle joint: A double blind clinic al trial (Translated from German). Allgemeinmedizin 1990, 19, 178-182.

100. Zuschlag, J.M. Double-blind clinical study using certain proteolytic enzyme mixtures in karate fighters: Working paper. Gerestsried Ger. Mucos Pharma GmbH 1988, 1-5.

101. Deitrick, R.E. Oral proteolytic enzymes in the treatment of athletic injuries: A double-blind study. Pa. Med. 1965, 68, 35-37.

102. Rathgeber, W.F. The use of proteolytic enzymes (chymoral) in sporting injuries. South Afr. Med. J. 1971, 45, 181-183.

103. Masson, M. Bromelain in blunt injuries of the locomotor system. A study of observed applications in general practice. Fortschr. Med. 1995, 113, 303-306.

104. Woolf, R.M.; Snow, J.W.; Walker, J.H.; Broadbent, T.R. Resolution of an Artifically Induced Hematoma and the Influence of a Proteolytic Enzyme. J. Trauma Acute Care Surg. 1965, 5, 491-494. [CrossRef] [PubMed]

105. Büttner, L.; Achilles, N.; Böhm, M.; Shah-Hosseini, K.; Mösges, R. Efficacy and tolerability of bromelain in patients with chronic rhinosinusitis-A pilot study. B-ENT 2013, 9, 217-225. [PubMed]

106. Helms, S.; Miller, A. Natural treatment of chronic rhinosinusitis. Altern. Med. Rev. A J. Clin. Ther. 2006, 11, $196-207$.

107. Seltzer, A.P. Adjunctive use of bromelains in sinusitis: A controlled study. Eye Ear Nose Throat Mon. 1967, 46, 1281-1285.

108. Ryan, R.E. A Double-Blind Clinical Evaluation of Bromelains in the Treatment of Acute Sinusitis. Headache J. Head Face Pain 1967, 7, 13-17. [CrossRef]

109. Bhui, K.; Tyagi, S.; Prakash, B.; Shukla, Y. Pineapple bromelain induces autophagy, facilitating apoptotic response in mammary carcinoma cells. BioFactors 2010, 36, 474-482. [CrossRef]

110. Bhui, K.; Tyagi, S.; Srivastava, A.K.; Singh, M.; Roy, P.; Singh, R.; Shukla, Y. Bromelain inhibits nuclear factor kappa-B translocation, driving human epidermoid carcinoma $A 431$ and melanoma A375 cells through $\mathrm{G}_{2} / \mathrm{M}$ arrest to apoptosis. Mol. Carcinog. 2011, 51, 231-243. [CrossRef]

111. Amini, A.; Moghaddam, S.M.; Ehteda, A.; Morris, L. Bromelain and N-acetylcysteine inhibit proliferation and survival of gastrointestinal cancer cells in vitro: Significance of combination therapy. J. Exp. Clin. Cancer Res. 2014, 33, 92.

112. Amini, A.; Moghaddam, S.M.; Morris, D.L. Bromelain. In Utility of Bromelain and N-Acetylcysteine in Treatment of Peritoneal Dissemination of Gastrointestinal Mucin-Producing Malignancies; Springer International Publishing: New York, NY, USA, 2016; pp. 63-80.

113. Pillai, K.; Akhter, J.; Chua, T.C.; Morris, D.L. Anticancer Property of Bromelain with Therapeutic Potential in Malignant Peritoneal Mesothelioma. Cancer Investig. 2013, 31, 241-250. [CrossRef]

114. Beuth, J.; Van Leendert, R.; Schneider, B.; Uhlenbruck, G. Complementary medicine on side-effects of adjuvant hormone therapy in patients with breast cancer. In Vivo 2013, 27, 869-871. [PubMed]

115. Uhlenbruck, G.; VAN Leendert, R.; Schneider, B.; Beuth, J. Reduced side-effects of adjuvant hormone therapy in breast cancer patients by complementary medicine. In Vivo 2010, 24, 799-802. [PubMed]

116. Eckert, K.; Grabowska, E.; Stange, R.; Schneider, U.; Eschmann, K.; Maurer, H.R. Effects of oral bromelain administration on the impaired immunocytotoxicity of mononuclear cells from mammary tumor patients. Oncol. Rep. 1999, 6, 1191-1199. [CrossRef] [PubMed] 
117. Dhandayuthapani, S.; Perez, H.D.; Paroulek, A.; Chinnakkannu, P.; Kandalam, U.; Jaffe, M.; Rathinavelu, A. Bromelain-Induced Apoptosis in GI-101A Breast Cancer Cells. J. Med. Food 2012, 15, 344-349. [CrossRef]

118. Desideri, I.; Francolini, G.; Becherini, C.; Terziani, F.; Paoli, C.D.; Olmetto, E.; Loi, M.; Perna, M.; Meattini, I.; Scotti, V.; et al. Use of an alpha lipoic, methylsulfonylmethane and bromelain dietary supplement (Opera ${ }^{\circledR}$ ) for chemotherapy-induced peripheral neuropathy management, a prospective study. Med. Oncol. 2017, 34, 46. [CrossRef]

119. Juhasz, B.; Thirunavukkarasu, M.; Pant, R.; Zhan, L.; Penumathsa, S.V.; Secor, E.R.; Srivastava, S.; Raychaudhuri, U.; Menon, V.P.; Otani, H.; et al. Bromelain induces cardioprotection against ischemia-reperfusion injury through Akt/FOXO pathway in rat myocardium. Am. J. Physiol. Circ. Physiol. 2008, 294, H1365-H1370. [CrossRef]

120. Ley, C. A review of the use of bromelain in cardiovascular diseases. J. Chin. Integr. Med. 2011, 9, 702-710. [CrossRef] [PubMed]

121. Cirelli, M.G.; Smyth, R.D. Effects of Bromelain Anti-Edema Therapy on Coagulation, Bleeding, and Prothrombin Times. J. New Drugs 1963, 3, 37-39. [CrossRef]

122. European Medicines Agency-EMA/113587/2014. 2014. Available online: http://www.ema.europa.eu/docs/en_GB/document_ library/PIP_decision/WC500166523.pdf (accessed on 14 December 2015).

123. Errasti, M.E.; Prospitti, A.; Viana, C.A.; Gonzalez, M.M.; Ramos, M.V.; Rotelli, A.E.; Caffini, N.O. Effects on fibrinogen, fibrin, and blood coagulation of proteolytic extracts from fruits of Pseudananas macrodontes, Bromelia balansae, and B. hieronymi (Bromeliaceae) in comparison with bromelain. Blood Coagul. Fibrinolysis 2016, 27, 441-449. [CrossRef] [PubMed]

124. Ribeiro, J.S.; Barboza, A.D.S.; Cuevas-Suárez, C.E.; Da Silva, A.F.; Piva, E.; Lund, R.G. Novel in-office peroxide-free toothwhitening gels: Bleaching effectiveness, enamel surface alterations, and cell viability. Sci. Rep. 2020, 10, 1-8. [CrossRef]

125. Parravano, M.; Tedeschi, M.; Manca, D.; Costanzo, E.; di Renzo, A.; Giorno, P.; Barbano, L.; Ziccardi, L.; Varano, M.; Parisi, V. Effects of Macuprev ${ }^{\circledR}$ Supplementation in Age-Related Macular Degeneration: A Double-Blind Randomized Morpho-Functional Study Along 6 Months of Follow-Up. Adv. Ther. 2019, 36, 2493-2505. [CrossRef]

126. Lete, I.; Mendoza, N.; De La Viuda, E.; Carmona, F. Effectiveness of an antioxidant preparation with N-acetyl cysteine, alpha lipoic acid and bromelain in the treatment of endometriosis-associated pelvic pain: LEAP study. Eur. J. Obstet. Gynecol. Reprod. Biol. 2018, 228, 221-224. [CrossRef] [PubMed]

127. Hale, L.P.; Chichlowski, M.; Trinh, C.T.; Greer, P.K. Dietary supplementation with fresh pineapple juice decreases inflammation and colonic neoplasia in IL-10-deficient mice with colitis. Inflamm. Bowel Dis. 2010, 16, 2012-2021. [CrossRef]

128. Secor, E.R.; Szczepanek, S.M.; Castater, C.A.; Adami, A.J.; Matson, A.P.; Rafti, E.T.; Guernsey, L.; Natarajan, P.; McNamara, J.T.; Schramm, C.M.; et al. Bromelain Inhibits Allergic Sensitization and Murine Asthma via Modulation of Dendritic Cells. Evidence-Based Complement. Altern. Med. 2013, 2013, 1-9. [CrossRef] [PubMed]

129. Secor, E.R.; Carson, W.F.; Singh, A.; Pensa, M.; Guernsey, L.A.; Schramm, C.M.; Thrall, R.S. Oral Bromelain Attenuates Inflammation in an Ovalbumin-Induced Murine Model of Asthma. Evidence-Based Complement. Altern. Med. 2008, 5, 61-69. [CrossRef] [PubMed]

130. Cordts, T.; Horter, J.; Vogelpohl, J.; Kremer, T.; Kneser, U.; Hernekamp, J.-F. Enzymatic debridement for the treatment of severely burned upper extremities-Early single center experiences. BMC Dermatol. 2016, 16, 1-7. [CrossRef]

131. Rosenberg, L.; Shoham, Y.; Krieger, Y.; Rubin, G.; Sander, F.; Koller, J.; David, K.; Egosi, D.; Ahuja, R.; Singer, A. Minimally invasive burn care: A review of seven clinical studies of rapid and selective debridement using a bromelain-based debriding enzyme (Nexobrid ${ }^{\circledR}$ ). Ann. Burn. Fire Disasters 2015, 28, 264-274.

132. Singer, A.J.; Boyce, S.T. Burn Wound Healing and Tissue Engineering. J. Burn. Care Res. 2017, 38, e605-e613. [CrossRef]

133. Rosenberg, L.; Krieger, Y.; Bogdanov-Berezovski, A.; Silberstein, E.; Shoham, Y.; Singer, A.J. A novel rapid and selective enzymatic debridement agent for burn wound management: A multi-center RCT. Burns 2014, 40, 466-474. [CrossRef]

134. Hirche, C.; Almeland, S.K.; Dheansa, B.; Fuchs, P.; Governa, M.; Hoeksema, H.; Korzeniowski, T.; Lumenta, D.B.; Marinescu, S.; Martinez-Mendez, J.R.; et al. Eschar removal by bromelain based enzymatic debridement (Nexobrid ${ }^{\circledR}$ ) in burns: European consensus guidelines update. Burns 2020, 46, 782-796. [CrossRef] [PubMed]

135. Massimiliano, R.; Pietro, R.; Paolo, S.; Sara, P.; Michele, F. Role of bromelain in the treatment of patients with pityriasis lichenoides chronica. J. Dermatol. Treat. 2007, 18, 219-222. [CrossRef]

136. Zhou, W.; Ye, C.; Geng, L.; Chen, G.; Wang, X.; Chen, W.; Sa, R.; Zhang, J.; Zhang, X. Purification and characterization of bromelain from pineapple (Ananas comosus L.) peel waste. J. Food Sci. 2021, 86, 385-393. [CrossRef] [PubMed]

137. Yan, H.-M.; Xia, M.-F.; Wang, Y.; Chang, X.-X.; Yao, X.-Z.; Rao, S.-X.; Zeng, M.-S.; Tu, Y.-F.; Feng, R.; Jia, W.-P.; et al. Efficacy of Berberine in Patients with Non-Alcoholic Fatty Liver Disease. PLoS ONE 2015, 10, e0134172. [CrossRef] 